\title{
CULTIVATION TECHNIQUES FOR ANIMAL CORONAVIRUSES: EMPHASIS ON FELINE INFECTIOUS PERITONITIS VIRUS, CANINE CORONAVIRUS, TRANSMISSIBLE GASTROENTERITIS VIRUS, AND PORCINE HEMAGGLUTINATING ENCEPHALOMYELITIS VIRUS
}

\author{
Roger D. Woods and Ronald D. Wesley \\ USDA-ARS, National Animal Disease Center, P.O. Box 70, Ames, Iowa 50010
}

\begin{abstract}
SUMMARY: Techniques are described for the growth and characterization of some mammalian coronaviruses. Because of the fastidious nature of their growth requirements, most will replicate only in cells derived from the natural host or a closely related species. Fetal cat cells are used to grow FIPV, and porcine cells are used to grow TGEV and HEV. However, CCV will replicate in both feline and canine cells. Although all four of these viruses prefer to replicate in a cell in the stationary phase of growth, FIPV is able to replicate in an actively growing cell. Each virus causes a cytopathic effect in monolayer cell cultures under agar or media 18 to $72 \mathrm{~h}$ postinfection. Primary isolation of each virus from field specimens is difficult, although most can usually be isolated after 1 to 3 blind passages in the cell culture.
\end{abstract}

Key words: enteric cell lines; isolation; growth requirements; coronavirus.

\section{INTRODUCTION}

The Coronaviridae family of viruses has a worldwide distribution. These viruses cause economically important diseases in man and in domestic and laboratory animals (33). At the present time the group consists of 14 recognized viruses and 4 or more unclassified isolates. The viruses and their abbreviations are listed in Table 1. These viruses comprise four distinct antigenic groups plus a miscellaneous group (35). Generally these viruses infect epithelial cells of the respiratory tract [human coronavirus (HCV), infectious bronchitis virus (IBV), rat coronavirus ( $\mathrm{RCV})$, porcine respiratory coronavirus (PCV)] and epithelial cells of the gastrointestinal tract [bovine coronavirus (BCV), canine coronavirus (CCV), transmissible gastroenteritis virus (TGEV), turkey coronavirus (TCV), feline enteric coronavirus (FECV), human enteric coronavirus (HECV)]. In addition, feline infectious peritonitis virus (FIPV), mouse hepatitis virus (MHV), rabbit coronavirus ( $\mathrm{RbCV})$, and hemagglutinating encephalomyelitis virus (HEV) exhibit other tissue tropisms and alternate pathogenic mechanisms (40). The feline, murine, and avian coronaviruses will usually cause a mild or inapparent infection in adults, but usually a severe diarrheal disease and often death in neonatal animals (40). Basic studies on these viruses have been limited because of their fastidious growth in cell culture (14). Most coronaviruses will grow only in cells derived from the natural host animal or in cells from a closely related species $(33,35)$. Growth of $\mathrm{HCV}$, $H E C V$, and $R b C V$ in cell culture is difficult, whereas
MHV and $\mathrm{CCV}$ are capable of growing to high titers in more than one cell line (14). Within the last few years several members of the coronavirdae family (MHV, IBV, TGEV) have been studied intensively and serve as models for the molecular biology of the group $(7,20,32)$.

\section{MATERIALS}

\section{A. Equipment}

Water jacketed incubator, model 3158, Forma'

Centrifuge, model UV, IEC ${ }^{2}$

Laminar flow hood, Labgard model, NuAire ${ }^{3}$

Pipet-aid, tissue culture model, Drummond Scientific ${ }^{4}$

Freezer, biological to $-85^{\circ} \mathrm{C}$, no. $8339^{1}$

Freezer, liquid nitrogen, model LR-35-9, Union Carbide $^{5}$

B. Chemicals

Eagle's MEM with Earle's additives, no. 410-1500, GIBCO $^{6}$

Leibovitz L15, no. 430-13006

Sodium pyruvate, no. $320-1360^{\circ}$

Lactalbumin hydrolysate, no. $320-1250^{6}$

Gentamycin sulfate, $50 \mathrm{mg} / \mathrm{ml}$, Schering 7

Sodium bicarbonate, no. $810-1810^{6}$

Trypsin (1:250), no. 840-7250

Ethylenediamine tetraacetic acid (EDTA), no. $890-1266^{\circ}$

Fetal bovine serum, no. 309-6309

Glucose, no. 820-50236

Potassium chloride, no. P 5405, Sigma ${ }^{8}$

Phenol red, no. 870-1160 
TABLE

CORONAVIRUSES AND THEIR GROWTH IN TISSUE CULTURE

\begin{tabular}{|c|c|c|c|}
\hline Group $^{a}$ & Virus & Tissue culhure & Reterences \\
\hline I. & $\begin{array}{l}\text { HCV-229E } \\
\text { TGEV } \\
\text { CCV } \\
\text { FIPV } \\
\text { FECV } \\
\text { PCV }\end{array}$ & $\begin{array}{l}10 / 2^{\circ} \text { human embryo cells } \\
2^{\circ} \mathrm{ST} \\
2^{\circ} \text { fetal cat } \\
\text { canine } \mathrm{A}-72 \\
2^{\circ} \text { fetal cat } \\
2^{\circ} \text { fetal cat } \\
1^{\circ} \text { pig kidney }\end{array}$ & $\begin{array}{l}\text { Schmidt et al. (34) } \\
\text { McClurkin and Norman (22) } \\
\text { Crandell et al. (9) } \\
\text { Binn et al. (5) } \\
\text { Pedersen and Black }(28) \\
\text { Pedersen et al. (29) } \\
\text { Pensaert et al. (31) }\end{array}$ \\
\hline II. & $\begin{array}{l}\text { HCV-OCA3 } \\
\text { MHV } \\
\text { HEV } \\
\text { BCV } \\
\text { RbCV }\end{array}$ & $\begin{array}{l}1 \% / 2^{\circ} \text { human trachea tissue } \\
1 \% / 2^{\circ} \text { mouse embryo } \\
1 \% / 2^{\circ} \text { porcine embryo } \\
1 \% / 2^{\circ} \text { bovine embryo } \\
\text { unknown }\end{array}$ & $\begin{array}{l}\text { Macnaughton and Madge (2) } \\
\text { Davis and Macnaughton (10) } \\
\text { Andries (2) } \\
\text { Mebus et al. (23) } \\
\text { Small and Woods (37) }\end{array}$ \\
\hline III. & IBV & embryonated eggs & Cavanagh $(8)$ \\
\hline IV. & TCV & embryonated eggs & Adams and Hofstad (1) \\
\hline Misc & $\begin{array}{l}\text { HECV } \\
\text { RCV } \\
\text { PCV } \\
\text { Foal enteritis coronavirus (FCV) }\end{array}$ & $\begin{array}{l}\text { unknown } \\
1^{\circ} \text { rat cells } \\
\text { embryonated eggs } \\
\text { unknown }\end{array}$ & $\begin{array}{l}\text { Payne et al. }(27) \\
\text { Bhatt et al. }(4) \\
\text { Hirai et al. (13) } \\
\text { Bass and Sharplee (3) }\end{array}$ \\
\hline
\end{tabular}

"Antigenically cross-reacting viruses: $\quad 1^{\circ}=$ primary cell cultures; $\quad 2^{\circ}=$ secondary cell cultures.

C. Supplies

McClurkin swine testes cells (ST) (22) Ames, IA

Crandell feline kidney cells (CRFK) (9), ATCC CCL 94, ATCC 9

Secondary porcine thyroid cells (SPTh) (2), Ames, IA

Feline infectious peritonitis virus (FIPV) (30), UCD-1, Davis, CA

Canine coronavirus (CCV) (43), UCD-1, Davis, CA

Transmissible gastroenteritis virus (TGEV) (12), Wooster, $\mathrm{OH}$

Hemagglutinating encephalomyelitis virus (HEV) (25), $67 \mathrm{~N}$, Ames, IA

Tissue culture flasks, $75 \mathrm{~cm}^{2}$, Falcon ${ }^{10}$

Pipettes, plastic ${ }^{10}$

Millex filters, $0.22 \mu \mathrm{m}$, Millipore ${ }^{11}$

\section{PROCEDURE}

A. Preparation of solutions

1. Cell culture

All procedures should be performed under sterile conditions in a laminar flow hood. Standard sterilization techniques are used for all glassware, instruments, and media.

2. Trypsin-ethylenediamine tetraacetic acid solution (TV)

a. To a 1-liter volumetric flask, add $8.0 \mathrm{~g} \mathrm{NaCl}, 0.4$ g KCl, 1.0 g D-glucose, 0.58 g $\mathrm{NaHCO}_{3}, 1.0 \mathrm{~g}$ trypsin, $0.4 \mathrm{~g}$ EDTA, $0.2 \mathrm{~g}$ phenol red, and 1liter double-glass distilled water (DGDW). Adust $\mathrm{pH}$ to $7.0 \mathrm{using} 1.0 \mathrm{~N} \mathrm{HCl}$ or $1.0 \mathrm{~N}$ $\mathrm{NaOH}$ solution.

b. Filter through a $0.22-\mu \mathrm{m}$ filter.

c. Store in aliquots of 10 to $20 \mathrm{ml}$ frozen at $-20^{\circ} \mathrm{C}$.

3. Eagle's MEM (EMEM) a. In 1 liter DGDW dissolve 1 packet of EMEM dehydrated medium and add, $2.2 \mathrm{~g} \mathrm{NaHCO}_{3}$, $0.1 \mathrm{~g}$ sodium pyruvate, and $2.2 \mathrm{~g}$ lactalbumin hydrolysate, and adjust $\mathrm{pH}$ to 7.0 with $1.0 \mathrm{~N}$ $\mathrm{HCl}$ or $1.0 \mathrm{~N} \mathrm{NaOH}$ solution.

b. Filter through a $0.22 \mu \mathrm{m}$ filter.

c. Store in aliquots of 90 and $900 \mathrm{ml}$ at $4^{\circ} \mathrm{C}$.

4. Leibovitz ( $\mathrm{Ll} 15$ )

a. In 1 liter DGDW dissolve 1 packet of L15 dehydrated medium with L-glutamine. Adjust $\mathrm{pH}$ to 7.0 with $1.0 \mathrm{~N} \mathrm{HCl}$ or $1.0 \mathrm{~N} \mathrm{NaOH}$ solution.

b. Filter through a $0.22 \% \mu \mathrm{m}$ filter.

c. Store in aliquots of $90 \mathrm{ml}$ at $4^{\circ} \mathrm{C}$.

5. Cell culture and virus growth media

a. To $90 \mathrm{ml}$ of EMEM add $10 \mathrm{ml}$ of heat-inactivated $\left(56^{\circ} \mathrm{C}\right.$ for $30 \mathrm{~min}$ ) fetal bovine serum (FBS); use for the cultivation of swine testis (ST) and secondary porcine thyroid (SPTh) cells.

b. To $100 \mathrm{ml}$ of EMEM add $1.0 \mathrm{ml}$ of gentamycin; use for the growth of TGEV and HEV.

c. Combine $50 \mathrm{ml}$ of EMEM and $50 \mathrm{ml}$ of L15 medium, add $15 \mathrm{ml}$ of heat-inactivated FBS and $1.0 \mathrm{ml}$ of gentamycin; use for the cultivation of CRFK cells.

d. Combine $50 \mathrm{ml}$ of EMEM and $50 \mathrm{ml}$ of L15 medium, add $2 \mathrm{ml}$ of heat-inactivated FBS and $1.0 \mathrm{ml}$ of gentamycin; use for the growth of FIPV and CCV.

C. Preparation of cell cultures

1. Cell passage

a. Aspirate the medium off 3- to 5-d-old confluent cultures of ST or SPTh cells and add $3 \mathrm{ml}$ of TV solution to each $75-\mathrm{cm}^{2}$ flask. Incubate the cells 

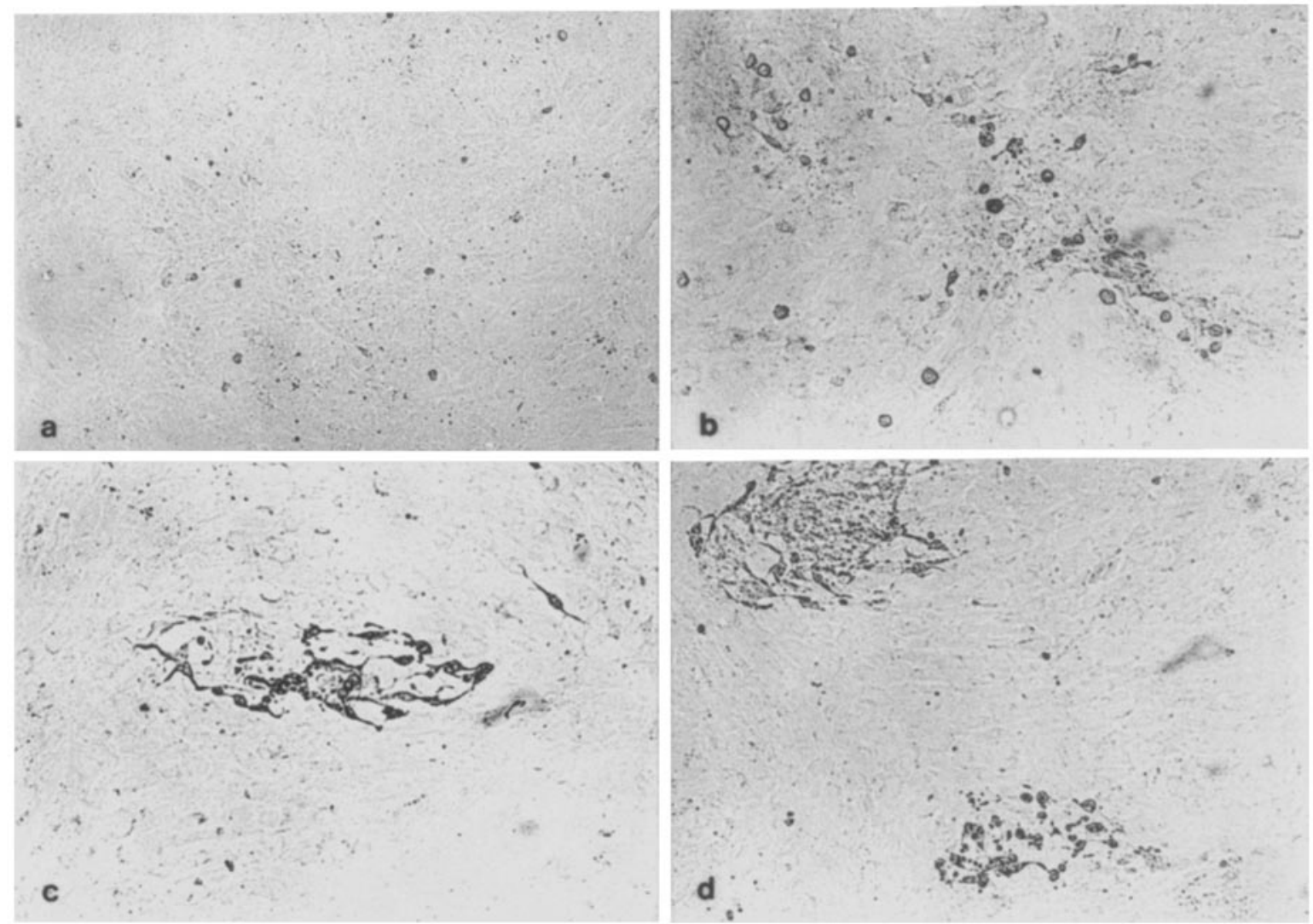

FIG. 1. a, Uninfected 5-d-old ST cells. $\times 70 . b$. Uninfected 5 -d-old SPTh cells. $\times 120 . c$, TGEV-infected ST cells $18 \mathrm{~h}$ PI. $\times 70 . d$, HEV-infected SPTh cells 24 h PI. $\times 120$. (Fig. $2 b$ and $d$ courtesy of $W$. L. Mengeling, Ames, Iowa. 1

and TV solution at room temperature for $5 \mathrm{~min}$. After incubation, pour off the TV solution and return the cells to the $37^{\circ} \mathrm{C}$ incubator for $2 \mathrm{~h}$. After incubation, resuspend the detached cells from one $75-\mathrm{cm}^{2}$ flask in $100 \mathrm{ml}$ of EMEM culture medium and distribute to five new 75 . $\mathrm{cm}^{2}$ flasks $(20 \mathrm{ml} / \mathrm{flask})$. This gives a seeding ratio of 1:5 (approx. 6 to 8 million cells/flask). After seeding, incubate the flasks at $37^{\circ} \mathrm{C}$ in a humidified incubator with $97 \%$ air: $3 \% \quad \mathrm{CO}_{2}$. Confluent monolayers of ST or SPTh cells are obtained within $5 \mathrm{~d}$ (Fig. $1 a, b$ ).

b. Aspirate the medium in one flask of 3- to 5-d-old confluent CRFK cells and replace with $3 \mathrm{ml}$ of $\mathrm{TV}$ solution. Incubate the cells and TV solution for $2 \mathrm{~min}$ at $20^{\circ} \mathrm{C}$. After incubation, pour off the TV solution and return the flask to the $37^{\circ} \mathrm{C}$ incubator for $30 \mathrm{~min}$. After incubation, resuspend the detached cells in $100 \mathrm{ml}$ of EMEM-L15 culture medium and distribute to five new $75-\mathrm{cm}^{2}$ flasks $(20 \mathrm{ml} / \mathrm{flask})$. This gives a seeding ratio of 1:5 (approx. 4 to 5 million cells/flask). Confluent CRFK monolayers are obtained within $3 \mathrm{~d}$ (Fig. 2 a).

D. Virus growth

\section{Virus}

Original stock viruses are maintained in glass, sealed ampules in liquid nitrogen. Stock working virus is within 10 passes of original source.
Working virus is frozen in EMEM with $20 \%$ FBS and maintained at $-75 \% \mathrm{C}$.

2. Virus growth

a. Remove one tube of FIPV and one tube of CCV from the $-75^{\circ} \mathrm{C}$ freezer and thaw at $37^{\circ} \mathrm{C}$. Remove two $75-\mathrm{cm}^{2}$ flasks of confluent (5-d-old) CRFK cells from the incubator and aspirate the spent medium. Rinse the cells twice with EMEM-L15 virus growth medium. Inoculate one flask with FIPV at a multiplicity of infection (MOI) of 0.05 to 0.5 plaque forming units (pfu)/cell ( 1 to $5 \mathrm{ml}$ of virus fluids) and inoculate the other flask with CCV at an MOI of 0.1 to $1.0 \mathrm{pfu} /$ cell ( 1 to $5 \mathrm{ml}$ of virus fluids). Return the flasks to the $37^{\circ} \mathrm{C}$ incubator for $1 \mathrm{~h}$. After incubation, remove the viral fluids from each flask and replace with $10 \mathrm{ml}$ of EMEML15 virus growth medium. Incubate the flask at $37^{\circ} \mathrm{C}$ until a viral-induced cytopathic effect (CPE) is observed. After CPE appears on approximately $25 \%$ of the cell sheet (Fig. $2 b, c$ ), freeze the flask at $-75^{\circ} \mathrm{C}$. Under the conditions described above, FIPV will have a titer of approximately 1 to $2 \times 10^{5} \mathrm{pfu} / \mathrm{ml}$ whereas $\mathrm{CCV}$ will have a titer of approximately $5 \times 10^{6}$ $\mathrm{pfu} / \mathrm{ml}$.

To obtain 5- to 10-fold higher titers of FIPV, the virus can be grown in CRFK cells while they are forming a monolayer. To do this, add 1 to 3 $\mathrm{ml}$ of FIPV fluid (MOI of 0.05 to $0.5 \mathrm{pfu} /$ cell) 

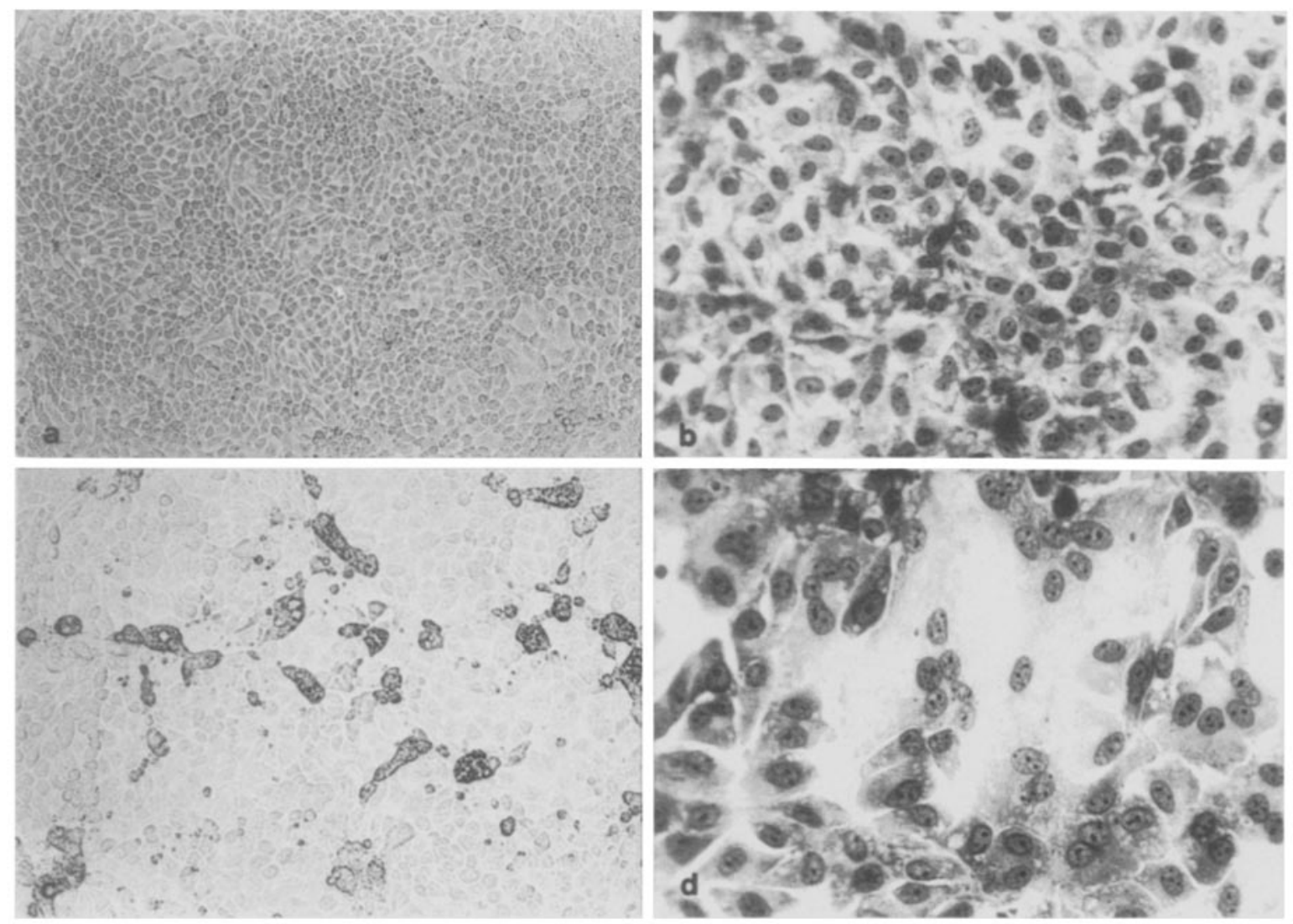

FIG. $2 a$, Uninfected 3 -d-old CRFK cells. $b$, FIPV-infected CRFK cells 48 h PI. $c$, CCV-infected CRFK cells 18 h PI. $d$,

TGEV-infected CRFK cells $30 \mathrm{~h}$ PI. $\times 70$.

and trypsin $(10 \mu \mathrm{g} / \mathrm{ml})$ to the cells after seeding. The CRFK cells will establish a confluent monolayer within $3 \mathrm{~d}$, and a viral-induced CPE will be observed $24 \mathrm{~h}$ later.

B. Remove one tube of TGEV and one tube of HEV from the $-75^{\circ} \mathrm{C}$ freezer and thaw at $37^{\circ} \mathrm{C}$. Remove one flask of 5-d-old ST cells and one flask of 5-d-old SPTh cells from the incubator. Aspirate the spent medium and rinse the cell sheets twice with serum-free EMEM. Inoculate ST flask with TGEV at an MOI of 0.1 to 2.0 $\mathrm{pfu} / \mathrm{cell}(0.1$ to $1.0 \mathrm{ml}$ of viral fluids), and inoculate the SPTh flask with HEV at an MOI of 0.1 to 2.0 $\mathrm{pfu} /$ cell 10.1 to $1.0 \mathrm{ml}$ of viral fluid). Incubate the flasks at $37^{\circ} \mathrm{C}$ for $1 \mathrm{~h}$. After incubation, aspirate the inoculum and replace with $10 \mathrm{ml}$ of serum-free EMEM. Return the flasks to the $37^{\circ} \mathrm{C}$ incubator and observe until approximately $25 \%$ of the cell sheet is showing CPE (Fig. $1 c$, d). After CPE is observed, freeze each flask at $-75^{\circ} \mathrm{C}$. When grown under these conditions, TGEV will have a plaque titer of approximately $7 \times 10^{7} \mathrm{pfu} / \mathrm{ml} 18$ to $20 \mathrm{~h}$ after inoculation, and HEV will have a plaque titer of approximately $3 \times 10^{7} \mathrm{pfu} / \mathrm{ml} 24$ to $48 \mathrm{~h}$ after inoculation.

\section{DISCUSSION}

To study the pathogenesis and molecular biology of coronaviruses, it is beneficial to identify cell lines in which the viruses will grow to titers greater than $5 \times 10^{5}$ $\mathrm{pfu} / \mathrm{ml}$, thus providing sufficient viral mass for molecular studies. At the present time, most of the animal coronaviruses have been adapted to cell culture $(14,33,35)$. The methods presented in this report are easy to reproduce and could be adapted by laboratories worldwide for in vitro growth of FIPV, CCV, HEV, and TGEV. Such procedures have been used to grow these viruses to titers ranging from about $1 \times 10^{6}$ $\mathrm{pfu} / \mathrm{ml}$ for FIPV (43) to $1 \times 10^{9} \mathrm{pfu} / \mathrm{ml}$ for TGEV (16).

Although most coronaviruses can now be grown in cell culture, their primary isolation from field specimens is still difficult (14). No one isolation technique or method can be used for the entire group. Probably the most successful isolation method is to blindly passage $0.2-\mu \mathrm{m}$-filtered fluids 1 to 3 times in a host organ cell line known to support growth of suspected virus, until a CPE is observed. The use of monospecific fluorescent antibodies is recommended to follow in vitro growth of the virus and to confirm virus identity. Several techniques have been used to enhance or improve the chances of isolating these viruses. Some of these techniques include addition of pancreatin $(0.5 \%)$, trypsin $(10 \mu \mathrm{g} / \mathrm{ml})$, or DEAE-dextran to cell culture media at the time of initial inoculation, maintaining a slightly acidic $\mathrm{pH}$ in the culture media, the use of primary cell cultures instead of secondary cultures, and incorporation of high titer hyperimmune antisera in the culture media to suppress the growth of contaminating viruses.

Coronavirus-induced CPE is dependent on the virus, cell line, and isolate. The CPE ranges from an inap- 
parent infection in persistently infected cell lines to nearly complete cell disruption with several cell cultureadapted viruses $(14,42)$. In a typical coronavirusinfected cell culture the first sign of CPE will be the appearance of granular and refractile cells, followed by formation of enlarged rounded cells, ballooned cells, and finally the detachment of infected cells from the culture flask (19). When grown under the conditions described, optimal viral titers are usually obtained when approximately $25 \%$ of the cell sheet is observed with CPE.

Both FIPV and CCV induce a similar CPE in CRFK cells. Thirty-six to $48 \mathrm{~h}$ postinfection (PI), FIPVinfected CRFK cells are granular and refractile. Over the next $24 \mathrm{~h}$ small multinucleated ( 8 to 10 nuclei) cells are formed by fusion and then they detach from the flask (9). The CPE is focal and under 0.5\% agar-MEM- $2 \%$ FBS, distinct plaques up to $1 \mathrm{~mm}$ in diameter form in the cell sheet in 48 to $72 \mathrm{~h}$. Initial CPE in CCV-infeeted CRFK appears within $12 \mathrm{~h}$ and consist of granular, refractile, and amorphorus multinucleated (greater than 10 nuclei) cells. During the next 12 to $24 \mathrm{~h}$ the CPE will spread over the entire sheet producing numerous ballooned cells and finally infected cells detaching from the flask. Under $0.5 \%$ agar-MEM, CCV will form distinct plaques $1.5 \mathrm{~mm}$ diameter within $48 \mathrm{~h}(5)$.

Initial CPE produced by attenuated and virulent TGEV in ST cells is similar to that observed with FIPV and CCV in CRFK cells, whereas CPE produced by HEV in SPTh cells is slightly different. Sixteen to $18 \mathrm{~h}$ PI, TGEV infected ST cells are granular, refractile, and greatly enlarged. Over the next 12 to $16 \mathrm{~h}$ the infection will spread over the cell sheet, and with advancing infection the round cells become ballooned and detach from the flask. Under $0.5 \%$ agar-MEM, attenuated TGEV produces clear uniform plaques up to $3 \mathrm{~mm}$ in diameter within $48 \mathrm{~h}$, whereas the virulent virus produces diffuse, irregular plaques approximately 0.5 to $1 \mathrm{~mm}$ in diameter within $48 \mathrm{~h}(19,42)$. In 24 to $48 \mathrm{~h}$ PI, HEV infected SPTh cells the CPE will show small areas of syncytia, which are easily visible with an inverted microscope. Over the next $24 \mathrm{~h}$ the syncytia degenerates, producing syncytial debris in the culture medium and clear holes with an opaque irregular shape in the cell sheet (2). After disruption of the syncytia, ballooned structures appear and the formation of new syncytia is seldom observed. A hemadsorption plaque assay has been developed for titration of infectivity of HEV (24).

The CRFK cell line has been used for the primary isolation and growth of FIPV. Isolation of FIPV from clinical specimens is very difficult using cell lines. However, virus can frequently be recovered if CRFK cells are inoculated and blindly passaged 1 to 3 times in the presence of trypsin (43). The incorporation of trypsin into the FIPV growth medium enhances both the isolation and growth of FIPV. The reason for this enhancement is unknown, but a similar observation has been recorded for $\mathrm{BCV}, \mathrm{IBV}$, and $\mathrm{MHV}(39,40)$. In addition to CRFK cells, a fetal cat whole fibroblast (FCWF) cell line will support the growth of FIPV, as well as FECV, CCV, and TGEV $(28,43)$, and com- parison of antigenic and serologic relatedness of the enteric coronaviruses was done in this cell line (43). One to three cell culture passages of virulent FIPV in CRFK or FCWF cells do not destroy its virulence for susceptible cats. A vaccine produced with a CRFK cell culture attenuated strain was unable to protect cats against the original virulent strain, although vaccinated cats do develop a neutralizing antibody response (27). Using cDNA clones of cell-culture-adapted FIPV, the complete nucleotide sequence of the FIPV peplomer protein has been determined (15).

The CRFK and A-72 (5) cell lines can be used for the isolation and propagation of CCV. This virus will grow to a titer of $1 \times 10^{7} \mathrm{pfu} / \mathrm{ml}$ or higher in either cell line. In addition, CCV can be adapted to grow in FCWF and ST cells. However, neither CCV nor FIPV will grow on primary isolation in ST cells, and this property may allow one to biologically differentiate these antigenically related coronaviruses. A single passage of $\mathrm{CCV}$ in CRFK cells does not decrease the infectivity for the natural host; however, prolonged serial passage in any cell line may result in an attenuated virus that grows well in cell culture but is avirulent for dogs. A cellculture-adapted CCV vaccine has been prepared and provides dogs vaccinated either i.m. or s.c. with neutralizing antibodies that are protective against a virulent $\mathrm{CCV}$ challenge (11).

The SPTh cell line can be used for the primary isolation of virus from clinical specimens and for the in vitro growth of HEV (2). Although virus grown in cell culture is still infective for pigs, it is less virulent than field strains (W. L. Mengeling, Ames, IA, personal communication I. No vaccine is currently available for this virus.

The ST cell line has been used for more than 20 yr to grow TGEV (22). This cell line can be used for primary isolation of virus from clinical specimens and in vitro growth of TGEV (10). Virus from clinically positive animals will usually have a titer near $1 \times 10^{5} \mathrm{pfu} / \mathrm{ml}$, and after 1 or 2 passages in ST cells it may have a titer of 1 to $2 \times 10^{7} \mathrm{pfu} / \mathrm{ml}$. Passage of the virus in serum-free media in 5-d-old ST cells at an MOI of 0.5 produces a maximum virus titer 18 to $24 \mathrm{~h}$ postinoculation. Subpassage of the virus under the same conditions in ST cells that are less than $4 \mathrm{~d}$ old or more than $7 \mathrm{~d}$ old will produce a lower virus titer (38). Cell-culture-adapted TGEV is still infective for pigs after 150 passages in ST cells, but pig virulence is usually reduced after only 10 to 15 passages in $\mathbf{S} \mathbf{T}$ cells. Three tissue-culture-adapted, modified-live TGEV vaccine strains are sold for use against virulent TGEV in pregnant swine. Two of the vaccine viruses are grown in porcine cell lines, and the source of the third vaccine virus is unknown. Although the safety and ability of these vaccines to elicit virusneutralizing antibodies in pregnant swine has been proven, their efficacy has been questioned $(6,26)$. The complete nucleotide sequence of the three major structural proteins of TGEV has been determined on cDNA clones of attenuated virus grown in ST cell culture $(15,17,18,32)$. 


\section{REFERENCES}

1. Adams, N. R.; Hofstad, M. S. Isolation of transmissible enteritis agent of turkeys in avian embryos. Avian Dis. 15:426-433; 1971.

2. Andries, K.; Pensaert, M. Propagation of hemagglutinating encephalomyelitis virus in porcine cell culture. ZBl. Vet. Med. B $27: 280-290 ; 1980$

3. Bass, E. P.; Sharplee, R. L. Coronavirus and gastroenteritis in foals. Lancet 2(7939):822; 1975.

4. Bhatt, P. N.; Perey, D. H.; Jonas, A. M. Characterization of the virus of sialodacryoadenitis of rats: a member of the coronavirus group. $J$. Infect. Dis. 126:123-130; 1972.

5. Binn, L. N.; Marchivicki, R. H.; Stephanson, E. H. Establishment of a canine cell line: derivation, characterization and viral spectrum. Am. J. Vet. Res. 41:855-860; 1980.

6. Bohl, E. H. Vaccination against transmissible gastroenteritis (TGE): Pros and Cons. In: Underdahl, N. R., ed. Proc. George A. Young Conf. Lincoln, NE: U. NE Press; 22:77-81; 1982.

7. Boursnell, M. E. G.; Brown, T. D. K.; Foulds, I. J., et al. The complete nucleotide sequence of avian infectious bronchitis virus: analysis of the polymerase-coding region. Adv. Exp. Med. Biol. 218:15-30; 1987.

8. Cavanagh, D. Structural polypeptides of coronavirus IBV. J. Gen. Virol. 53:93-103; 1981.

9. Crandell, R. A.; Fabricant, C. G.; Nelson-Rees, W. A. Development, characterization and viral susceptibility of a feline (Felis catus) renal cell line (CrFK). In Vitro 9:176-185; 1973.

10. Davis, H.; Macnaughton, M. R. Comparison of the morphology of three coronaviruses. Arch. Virol. 59:25-33; 1979.

11. Edwards, B. G.; Fulker, R. H.; Acree, W. M., et al. Evaluating a canine coronavirus vaceine through antigen extinetion and challenge studies. Vet. Med. (SAC) 80:28-33; 1985.

12. Frederick, G. T.; Bohl, E. H. Local and systemic cell mediated immunity against transmissible gastroenteritis; an intestinal infection of swine. J. Immunol. 116:1000-1004; 1976.

13. Hiria, K.; Hitchner, S. B.; Calnek, B. W. Characterization of new coronavirus-like agent isolated from parrots. Avian Dis. 23:515-525: 1979.

14. Holmes, K. V. Replication of coronaviruses. In: Field, B. N., ed. Virology. New York, NY: Raven Press; 1985:1331-1342.

15. Jacobs, $L_{\text {; }}$ deGroot, R.; van der Zeijst, B. A. M., et al. The nucleotide sequence of the peplomer gene of porcine transmissible gastrnenteritis virus (TGEV): comparison with the sequence of the peplomer protein of feline infectious peritonitis virus (FIPV). Virus Res. 8:363-371; 1987.

16. Jimeniz, G.; Correa, I.; Melgosa, M., et al. Critical epitopes in transmissible gastroenteritis virus neutralization. J. Virol. 60:131-139; 1986.

17. Kapke, P. A.; Brian, D. A. Sequence analysis of the porcine transmissible gastroenteritis coronavirus nucleocapsid protein. Virology 151:41-49; 1986.

18. Kapke, P. A.; Tung, F. Y. C.; Brian, D. A., et al. Nucleotide sequence of the porcine transmissible gastroenteritis coronavirus matrix protein gene. Adv. Exp. Med. Biol. 218:117-122; 1987.

19. Kemeny, L. J. Isolation of transmissible gastroenteritis virus from pharyngeal swabs obtained from sows at slaughter. Am. J. Vet. Res. 39:703-705; 1978 .

20. Lai, M. M. C. Overview: molecular biology of coronaviruses 1986. Adv. Exp. Med. Biol. 218:7-14; 1987

21. Macnaughton, M. R.; Madge, M. H. The genome of human coronavirus strain 229E. J. Gen. Virol. 39:497-504; 1978.

' Forma Scientific, Marietta, $\mathrm{OH}$

${ }^{2}$ International Equipment Co., Boston, MA

${ }^{3}$ NuAire, Inc., Plymouth, MI

+ Drummond Scientific Co., Broomall, PA

${ }^{3}$ Union Carbide, Linde Division, New York, NY

- GIBCO Laboratories, Grand Island, NY
22. McClurkin, A. W.; Norman, J. O. Studies on transmissible gastroenteritis of swine. II. Selected characteristics of a cytopathogenic virus common to five isolates from transmissible gastroenteritis. Can. J. Comp. Vet. Sci. 30:190-198; 1966

23. Mebus, C. A.; Stair, E. L.; Rhodes, M. B., et al. Neonatal calf diarrhoea; propagation, attenuation, and characterization of a coronavirus-like agent. Am. J. Vet. Res. 34:145-150; 1973.

24. Mengeling, W. L. Hemadsorption plaque assay for hemagglutinating encephalomyelitis virus. Am. J. Vet. Res. 33:2075-2080; 1972 .

25. Mengeling, W. L; Boothe, G. D.; Ritehie, A. E. Characteristics of a coronavirus (strain 67N) of pigs. Am. J. Vet. Res. 33:297-308; 1972.

26. Moxley, R. A.; Olsen, L. D. Comparison of TGEV vaccines. In: MeKean, J., ed. Proc. Int. Vet. Soc. Cong, Barcelona, Spain: Int. Pig Vet. Soc. $9: 191 ; 1986$.

27. Payne, C. M.; Ray, C. G.; Borduin, V., et al. An eight-year study of the viral agents of acute gastroenteritis in humans: ultrastructural observations and seasonal distribution with a major emphasis on coronavirus. Adv. Exp. Med. Biol. 218:579-580; 1987.

28. Pedersen. N. C.; Black. J. W. Attempted immunization of cats against feline infectious peritonitis; using avirulent live virus or sublethal amounts of virulent virus. Am. J. Vet. Res. 44:229-234; 1983.

29. Pedersen, N. C.; Boyle, J. F.; Floyd, K. Infection studies in kittens using feline infectious peritonitis virus propagated in cell culture. Am. J. Vet. Res. 42:363-367; 1981.

30. Pedersen, N. C.; Ward, J.; Mengeling, W. L. Antigenic relationship of the feline infectious peritonitis virus to coronaviruses of other species. Arch. Virol. 58:45-53; 1978.

31. Pensaert, M.; Callebaut, P.; Vergote, J. Isolation of a porcine respiratory, non-enteric coronavirus related to transmissible gastroenteritis. Vet. Qt. $8: 257-261 ; 1986$.

32. Rasschaert, D.; Laudv, H. The predicted primary structure of the peplomer protein E2 of the porcine coronavirus transmissible gastroenteritis virus. J. Gen. Virol. 68:1883-1890; 1987.

33. Robb, J. A.; Bond, C. W. Coronaviridae. In: Fraenkel-Conrat, H.; Wagner, R. R., eds. Comprehensive Virology, vol. 14. New York, NY: Plenum Press; 1979:193-247.

34. Schmidt, 0. W.; Cooney, M. K.; Kenny, G. E. Plaque assay and improved yield of human coronavirus in a human rhabdosarcoma cell line. $J$. Clin. Microbiol, 9:722-728; 1979.

35. Siddell, S.; Wege, H.; ter Meulen, V. The structure and replication of coronaviruses. Curr. Top. Microbiol. Immunol, 99:131-163; 1982.

36. Siddell, S.; Wege, H.; ter Meulen, V. The biology of coronaviruses. J. Gen. Virol. 64:761-776; 1983

37. Small, J. D.: Woods. R. D. Relatedness of rabbit coronavirus to other coronaviruses. Adv, Exp. Med. Biol. 218:521-528; 1987.

38. Stark, S. L.; Fernelius, A. L.; Boothe, G. D., et al. Transmissible gastroenteritis (TGE) of swine: elfect of age of swine testes cell culture monolayers on plaque assays of TGE virus. Can. J. Comp. Med. $39: 466-468 ; 1975$

39. Storz, J.; Rott, R.; Kaluza, G. Enhancement of plaque formation and cell fusion of an enteric pathogenic coronavirus by trypsin treatment. Infect. Immunol. 31:1212-1222; 1981.

40. Sturman, L. S.; Holmes, K. V. The molecular biology of coronaviruses. Adv. Virus. Res. 28:35-112; 1983.

41. Wege, H.; Siddell, S.; ter Meulen, V. The biology and pathogenesis of coronaviruses, Curr. Top. Microbiol. Immunol. 99:165-200; 1982.

42. Woods, R. D. Small plaque variant transmissible gastroenteritis virus. J. Am. Vet. Med. Assoc. 173:643-647; 1978.

43. Woods, R. D. Studies of enteric coronaviruses in a feline cell line. Vet. Microbiol. 7:427-435; 1982

\footnotetext{
'Schering Corp., Kenilworth, NJ

${ }^{8}$ Sigma Chemical Co., St. Louis, MO

- American Type Culture Collection, Rockville, MD

${ }^{10}$ Falcon Division, Beckton Dickinson and Co., Orangeburg, NY

"Millipore Corp., Bedlord, MA
} 